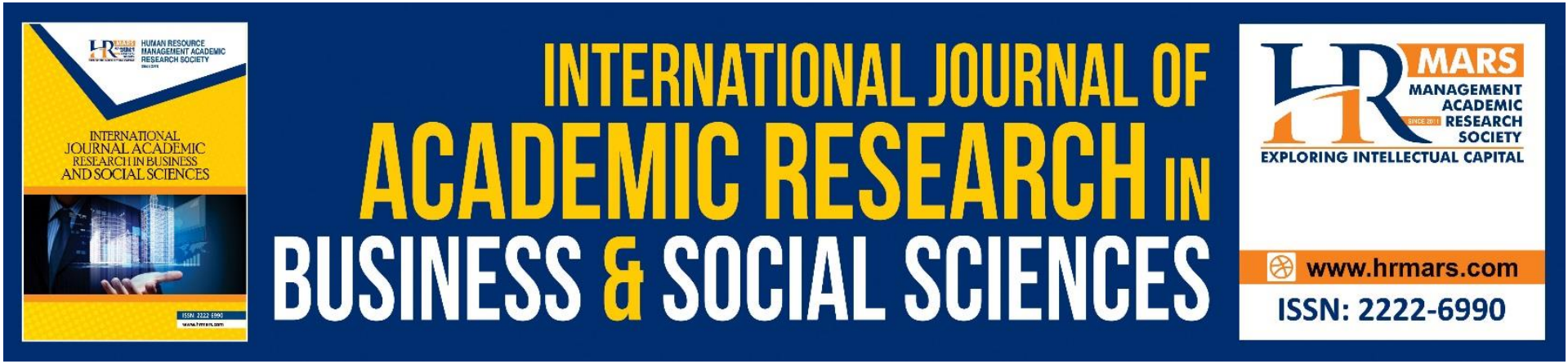

\title{
Systematic Literature Review of Language Learning Strategies for Reading Skills in English for Specific Purposes among Business Students
}

\section{Nurzawanah Rohaizat, Azlina Abdul Aziz}

To Link this Article: http://dx.doi.org/10.6007/IJARBSS/v11-i12/11522 DOI:10.6007/IJARBSS/v11-i12/11522

Received: 13 October 2021, Revised: 17 November 2021, Accepted: 30 November 2021

Published Online: 14 December 2021

In-Text Citation: (Rohaizat \& Aziz, 2021)

To Cite this Article: Rohaizat, N., \& Aziz, A. A. (2021). Systematic Literature Review of Language Learning Strategies for Reading Skills in English for Specific Purposes among Business Students. International Journal of Academic Research in Business and Social Sciences, 11(12), 139-159.

Copyright: (c) 2021 The Author(s)

Published by Human Resource Management Academic Research Society (www.hrmars.com)

This article is published under the Creative Commons Attribution (CC BY 4.0) license. Anyone may reproduce, distribute, translate and create derivative works of this article (for both commercial and non0-commercial purposes), subject to full attribution to the original publication and authors. The full terms of this license may be seen at: http://creativecommons.org/licences/by/4.0/legalcode

Vol. 11, No. 12, 2021, Pg. $139-159$

Full Terms \& Conditions of access and use can be found at http://hrmars.com/index.php/pages/detail/publication-ethics 


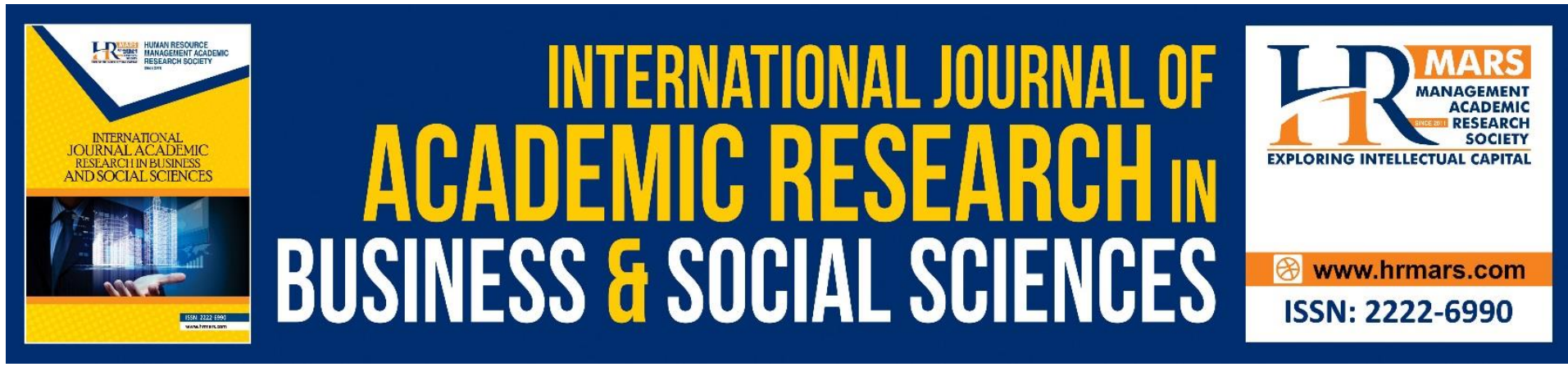

\title{
Systematic Literature Review of Language Learning Strategies for Reading Skills in English for Specific Purposes among Business Students
}

\author{
Nurzawanah Rohaizat ${ }^{1,2}$, Azlina Abdul Aziz ${ }^{2}$ \\ ${ }^{1}$ General Studies Department, Politeknik Sultan Abdul Halim Mu'adzam Shah, 06000 Jitra, \\ ${ }^{2}$ Faculty of Education, Universiti Kebangsaan Malaysia, 43600 Bangi \\ Email: nurzawanah@polimas.edu.my
}

\begin{abstract}
This article analyses English language learning strategies adopted by students in learning English for Specific Purposes (ESP). Despite a broad study in language learning, there is still a scarcity of empirical evidence to emphasise the importance of LLS and the impact on students' performance for ESP specifically. This topic is significant in reflecting the strategies and their adaptability by targeted students. It involves a systematic review of literature and studies from Malaysia and other parts of the world between 2009 and 2021. It references published research studies, analyses books and strategies students use in learning English and especially for specific purposes and reading skills. Out of 50 previous studies, 20 were chosen for a thorough analysis ranging from research journals, reports, and books on definitions and growth and development of ESP, and strategies for learning ESP. The studies revealed that though the majority of ESP students in Malaysia have embraced self-directed English language learning strategies, there is still a gap in the English proficiency in the Malaysian education system. While acknowledging the limitation occasioned by a smaller sample size, the study recommended the adoption of language learning from an out-of-classroom perspective and understanding the significance of Business English to students.
\end{abstract}

Keywords: Language Learning Strategies (LLS), English for Specific Purposes (ESP), Reading Skills, Business English

\section{Introduction}

In language learning, the aspect of reading is a special component that plays the role of promoting vocabulary development and expansion in students. Reading assists the learners in the development of cognitive skills and enhances their level of comprehension on the different disciplines they undertake. The importance of reading skills in the development of learners' knowledge is highlighted by Uribe-Enciso (2015). He suggests that reading skills development assists in the development of written discourses and the syntactic structures of languages. Students are assisted through reading in the development of their critical, imaginative, analytical, evaluative, judgmental, and problem-solving skills (Benraghda, Radzuan \& Ali, 2017). 
In this article, an analysis of English language learning strategies adopted by students in learning English for Specific Purposes is undertaken. A systematic review of available literature regarding the subject matter is carried out, especially concerning Malaysia and other parts of the world. The report references published research studies, an analysis of books and strategies students use in learning English and especially for specific purposes. The paper contains parts such as the criteria used to collect the research papers, a critical analysis of the papers, the criteria used for the investigation, the findings from the literature reviewed, gaps in the explored research, and the significance of the study.

ESP students need to have a firm grasp of the vocabulary used in their subjects and in the real world. For example, while speaking in the corporate world is important, learning how to carry out business-related responsibilities is vital for business students (Benraghda, Radzuan \& Ali, 2017). The general business settings involve making business reports, delivering presentations, expressing opinions, and conducting meetings. In addition to the mentioned, other aspects of Business English, involve constructing emails, writing letters, making applications for different roles, and understanding various job profiles (Damanik, 2020).

In general, learning English for Specific Purposes prepares students for life in corporations and office settings. Using the business example, knowledge in Business English prepares students for the general corporate world and specific areas they choose to venture in, such as law, politics, finance, marketing, and engineering. To be able to assist in advancing English for Specific Purposes, a needs assessment and analysis are vital (Nambiar, 2007). Proficiency is one aspect of ESP that can be used to evaluate students. It can also help to know their needs and design strategies that can be adopted in helping students learn English for Specific Purposes.

\section{Research Objectives}

The main goals of this systematic literature review are making a presentation and synthesising the empirical evidence available from previous related research studies on the strategies that can be adopted to improve ESP learners, their comprehension of the various disciplines' subject matters and the teachers.

The objectives of the study were:

i. To examine the English Language Learning strategies adopted by ESP Students for reading skills.

ii. To examine the effectiveness of the English Language Learning Strategies for reading comprehension employed by the ESP students

\section{Research Questions}

This study aims at identifying the available literature concerning English Language Learning strategies and especially to ESP students. Although there have been studies on the subject matter, a minority of the studies have been focused on the need assessment, implications on the same on students and teachers, etc. For this study, the following questions guided the scope of the study:

i. What strategies with regard to reading can be used to teach ESP learners in improving their comprehension during the reading process?

ii. What is the existing literature regarding English for Specific Purposes?

iii. What are the general characteristics of teaching and learning in ESP? 
iv. Which business students can adopt English language learning strategies in learning ESP?

v. What is the status of ESP in the context of Malaysia in general?

\section{Literature Review}

In this chapter, a review of the available literature will be done concerning the main issues affecting reading strategies. The report will also address English for Specific Purposes. The study will first deal with the relevant definitions of ESP, its growth and development until the level of becoming Business English. The importance of speaking and writing in ESP is also addressed.

\section{Development of English for Specific Purposes (ESP)}

The emergence of ESP began early in the 1960s, and the sector has continued to grow with each passing day. After English became a lingua franca, the values, interests, and ESP need have multiplied immensely. Technological advancements and the growth in science have contributed to the need for ESP courses. In addition to this, business development, industrialisation, and globalisation have led to proper and efficient communication means. English has become the international vehicle of communication. Although not yet fully developed, ESP is in the process of development involving some stages. All the steps have always revolved around language, and ESP has been mainly concerned with preparing students to develop communication skills, creativity, and professionalism. There have been factors that have led to the development of ESP, according to (Damanik, 2020).

The birth of ESP has been attributed to three factors, namely, the demands of the changing world, developments in linguistics, and a shift of focus towards the students. In its development, ESP has undergone numerous stages, which have been discussed briefly below. The first stage can be dated back to the late 1960s and the early years of 1970 . The emergence of ESP can be linked with Peter Strevens. The core component of this aspect was that it based its argument on the assumption that each discipline establishes a register specific to it. The belief made was that each body, such as science, biology, and engineering establish its particular register. The analysis on the register, in general, did not show anything new to what was already in existence in General English. However, register analysis aimed to come up with syllabi that consider learners' needs.

The second stage of ESP development involved an analysis of rhetoric or discourse. The two main pioneers of the second stage are Lackstorm, Selinker, and Trimble in 1973. During this phase, two sub-stages also occurred. The first stage was involved in studying the structure of a sentence. The second level shifted the attention from the sentence structure to a notch higher. Instead of generally dealing with the structure of a sentence, the ESP became concerned with rhetorical analysis. In this stage, a line is drawn between commercial texts and the rhetorical structure of the texts.

The third stage of ESP development involved an analysis of the target situation. In this stage, an attempt is made towards setting the present knowledge on a more systematic grounding. The designing of an ESP course should involve identifying the target situation and then making scrutiny of the linguistic features of such a scenario. It is in this phase where students' needs are analysed with the aim of meeting them.

The next phase involves skills and strategies. An approach that is skill-centred focuses on developing skills and strategies that students require to understand and deduce meanings from any discourse they face. It is important to ensure that the reading and listening 
strategies are employed in this context appropriately. The last step is a learning-centred approach. In this regard, the focus is shifted from language description to language learning. The other four phases have all been concerned with describing language rather than its learning. An approach that is learning-centred is concerned with how language is normally taught. The main emphasis is given on grammar, the use of the dictionary, and reading books to learn about languages. This phase is focused on the comprehension of the processes of learning a language.

\section{English for Specific Purposes (ESP)}

After preliminary reviews of available literature, ESP is noted to have been studied repeatedly. This means that various definitions have also been brought forward. However, there has not been a unanimous agreement on the most basic definition of ESP in general. A claim by Dudley-Evans and St. John (1998) depicts ESP to have no relationship with the content. However, they claim that it should always reflect underlying concepts and activities of a broader discipline. This statement means that ESP does not have to directly correlate with specific disciplines that students' study (Mazli, 2007). That being said, it should, however, reflect a business context with authenticity. The strategies used in teaching ESP should show a reflection of the disciplines or the careers it serves.

An observation by Ahmad (2007) contradicts the claims made by the mentioned authors. The research suggests that ESP has a direct relationship with the contents of the specific subjects. This means that there is a level of direct specificity that should be maintained regarding the topics, vocabulary or skills, and the related discipline's contents. He claims that the activities conducted, and the content taught in class should reflect an authentic and appropriate business atmosphere. The advantage of this is that students will acquire the relevant skills to help them deal with given situations appropriately and efficiently. Ahmad (2007) argues that there should be a concrete link between ESP teaching and the contents of the discipline. To mediate between their ideology and that of Ahmad (2007), Dudley-Evans and St. John (1998) modified the definition of ESP. The two presented two main characteristics: absolute and variable.

Concerning absolute characteristics, they defined ESP as being designed to meet the specific needs of students and make use of underlying activities and techniques of the discipline served. Absolute features were identified, showing ESP to be centred on the language, appropriate genres, discourse, and skills. Concerning language, it means the overall sense of lexis, grammar, and the register.

Variable characteristics showed that the ESP can have a relationship with special disciplines. It also indicated that ESP might utilise varying methodologies from those employed in general English. Adult learners were also found to have a higher likelihood of being designated to ESP during their tertiary education or professional work. Lastly, ESP was generally designed for middle students but could be of help to beginners (Ismail, 2008).

Damanik (2020) suggested that the ESP approach to learning a language was founded on the student's decision to learn and their reasons behind it. They claimed that such an approach to language teaching had the methodology and content dependent on the students' reasons for learning. This means that an assessment and analysis of the needs of the students was a key component of ESP. Taking into consideration the needs of the learners were a distinctive feature of ESP. The student's reasons for studying ESP should altogether be considered when designing the course. Courses dealing with ESP should be based on the needs analysis of the learners and should try and meet the special needs of each learner. 
Research studies concerning ESP are very few in Malaysia as applies to studies on Business English in the country. The relatively low numbers of studies that have been conducted involve students in institutions of higher education. According to Mustaffa (2006), the majority of undergraduate students lack the necessary note-taking skills. This translates into them experiencing problems with regard to participating in discussions and listening to lectures. The study pinpointed those students in universities and colleges were faced with challenges of transition. It is the expectation that the transition between secondary schools and universities or colleges be smooth for students. The expectations are based on the fact that the students will have the basic critical and literary skills and abilities required in meeting the academic demands of the institutions they join.

Ahmad (2007) showed that students were having limited critical abilities and could not respond appropriately to texts. The learners also lacked the conventions necessary for academic writing. Moreover, the results were faced with the challenge of writing well in the business discipline (Krishnakumari, Paul-Evanson, \& Selvanayagam, 2010). The study further showed that transitioning students do not get enough preparation in secondary school to meet the reading demands at the university level. Moreover, students in institutions of higher learning were discovered to have limited knowledge of vocabulary. The learners had a weak understanding of complex sentences. The vocabulary being a key component of academic reading, the students' performance was shown to be affected in areas dealing with contents of subjects and especially business (Ahmad, 2013).

Research by Aziz (2007) showed that learners in tertiary institutions were faced with language anxiety when it came to making presentations or speaking English. The study found out that the students felt more comfortable while using Bahasa Malaysia to communicate, either formally or informally.

To the end of this review, the literature explored shows the levels of English learning in the Malaysian scenario. The review illustrates the need for making a reassessment of the approaches used in teaching English as well as ESP. One of the standout recommendations is the incorporation of out-of-classroom activities and practices in learning. There is also the need to make deliberations about the socio-cultural impacts of Bahasa Malaysia on English literacy learning (Paltridge \& Starfield, 2014). The different researchers unanimously call for the assessment and understanding of the needs of learners to promote adequate learning among the students.

\section{Business English}

English for Specific Purposes has several aspects, one of which is Business English. ESP, in general, has two broad categories: English for Occupational Purposes (EOP) and English for Academic Purposes (EAP). EOP is concerned with English that is in close relationship with vocational or professional scopes or both. On the other hand, EAP is further sub-categorised into English for Specific Topics, English for Business and Economics, and English for Social Studies. Out of the three, English for Business and Economics is greatly developed compared to the rest. The reason behind this fact is that there has been an increasing demand in need for learners in various spheres such as management, finance, accounting, banking, and marketing (Ali, 2008).

There have been arguments that business English should be considered as the general context of ESP. This argument is made by Ellis and Johnson (1994) and supported by Chaka and Booi-Ncetani (2015). They suggest that business English shares the most vital components of needs assessment and analysis, design of syllabi and course, as well as the 
materials with the rest of the other fields. Business English is regarded as placing needs analysis at the forefront during the process of designing the course. The needs of the students include their specific objectives in the course and the type of language they prefer while conducting their classroom activities.

At the beginning of ESP, textbooks dealing with Business English presented vocabularies that were in written texts and dialogues connected to certain subjects. The books made assessments based on exercises that dealt with reading comprehension, definitions of particular words, and constructing sentence structures. This approach to the introduction of concepts was founded on the assumption that the student had prior knowledge of the language but could not apply the language in the contemporary world. This introductory approach did not involve activities related to interaction, communication and written correspondences.

When the focus is on reading alone, research has shown that it is an inadequate skill that students cannot depend on to become effective in communication in a business or related world. Having reading skills alone cannot enable learners to become effective in their communication within the business world and this has triggered researchers to find the suitable means of developing communication skills (Chaka \& Booi-Ncetani, 2015). Effective communication skills include reading, speaking, writing, and listening within the contexts of the corporate world. Although proponents of this theory are correct to some extent, they make a wrong assumption that all students have the basic knowledge of English grammar.

In the late 1970s and early 1980s, there was a shift in Business English to functional areas. This implies that there was an introduction of the aspect of giving opinions, agreeing, and disagreeing on ideas and concepts. Practical activities such as listening, booking appointments, etc., were introduced. Towards the end of the 1980s, there was real development in business English. Studies focused on improving the existing bodies of knowledge with a special focus on the development of students' skills. The learners' skills acquired for language usage needed ways to be honed and further developed. During this period, business books, articles, and journals were published. Companies gave the allowance for their employees to attend courses. The courses were intended to enable them to increase their proficiency and productivity in their job roles.

In the current world, communication should be effective and without the risk of misunderstanding. Wrong messages could be costly to a company and could damage the reputation of a corporation. Communication should be clear, specific, objective, and concrete. A business writer will prefer to use short sentences using simple language.

\section{Language Learning Strategies \\ Direct Strategies}

The direct learning strategies are important in the mastery of English language reading, writing, listening, and speaking skills. The ESP classroom stresses the application of metacognitive, compensation, and cognitive strategies to develop these critical language skills. The ESP teachers play the role of materials providers, course designers, evaluators, researchers, and learning collaborators to create a student-centered approach to learning that enhances successful mastery of English language skills (Chalikandy, 2013). Memory strategies are useful in language learning because they enable the student to store and retrieve information such as words and meaning. Thus, memory strategies boost the development of vocabulary and comprehension. Cognitive learning engages the senses in a conductive and long-lasting way, thereby enhancing memory and mastery of learned 
information. This active, immersive learning process improves reading, comprehension, and speaking skills through better retention capacity and memory. Nevertheless, Nambiar (2007) observed that excessive reliance on cognitive strategies such as heavy reliance on the dictionary to help read and understand a text might hamper the effectiveness of the development of reading skills.

\section{Indirect Strategies}

The metacognitive learning strategies effective for learning ESL include interactive discussions, relying on coursework for guidance, taking notes, using planning to organise thoughts, and practising writing (Jamalai \& Krish, 2021). Affective learning strategies focus on the students' attitudes, values, motivations, and perceptions towards learning. The study by Pandian (2002) found that a shift from knowledge-based rote learning to self-access learning that promotes independence and life-long learning had led to the development of critical thinking and other 21-century learning skills, attitudes, and perceptions that promote affective learning. Social learning strategies rely on factors in the social environment to promote learning. According to the findings of the study by Kavaliauskiene (2009), all learners need the support of their mother tongue in English classes to enhance the learning outcome.

\section{English Language Learning Strategies}

Developing an environment characterised by cultural responsiveness and mutual relationships is the first step in promoting English language learning. One way to show cultural responsiveness is to provide mother tongue support to enhance comprehension of words and contextual meanings (Kavaliauskienè, 2009). The second strategy is to teach English language skills across the school curriculum. As Ahmad (2013) observed, education systems should not equate language education exclusively to any specific learning institutions; rather, they ought to distribute language learning throughout all phases of learning. Other than incorporating native language in the learning process, there is the need to adopt the use of technology in English language learning. Azmuddin et al (2020) observed that students in an online reading environment attained better reading comprehension facilitated by digital annotation tools. These findings reiterate the importance of adopting technology to promote learning of the English language.

\section{Reading Skills}

Decoding, understanding the meaning of a word in a context or of a sentence in a paragraph is one of the most important reading skills. Fluency in the pronunciation of words is the second most important reading skill. Other skills include vocabulary and sentence construction and cohesion. Jamalai and Krish (2021) recommended the use of online discussion forums (ODF) to promote linguistic skills through knowledge sharing and discussions on the assigned group tasks. The ODF provides a platform for promoting mastery of sentence construction and cohesion skills as well as language vocabulary. The ODF further enhances reasoning and background knowledge, which are important for successful reading of passages. Attention and working memory are critical reading skills that students develop through continuous practice in an environment that supports learning of the English language. 


\section{The Case for Malaysia \\ Research on English Language Learning in Malaysia}

After reviewing research studies carried out to examine English learning in schools in Malaysia, findings show that the national language (Bahasa Malaysia) has a huge influence over the former. Some of the studies conducted can be discussed as follows:

A study conducted to determine the level of interference of Bahasa Malaysia by Maros, Hua, and Salehuddin (2007) shows that the national language is a big inhibitor to English acquisition. The study was conducted on Form One students, and after analysis of the errors in the students' essays, it was found out that mother tongue interference was a significant factor. The 120 students were prone to making errors in the use of articles and had problems in making sentences with a subject-verb agreement. However, the study also found out that although the majority of the students were influenced by Bahasa Malaysia to make mistakes, other factors had been left out of the study, such as the attitudes of the students and perceptions of their teachers towards the English language.

Another research study by Jalaludin et al (2008) examines the syntactical and morphological alterations between English and Bahasa Malaysia. The work concludes that differences in linguistics are the number-one factor influencing the ability of students to learn English. The study was conducted on over 300 students and showed that the students had major weaknesses in grammar and especially syntax and morphology. The study indicated that the form two students have difficulties in affixes and plural. The reason behind this was that Bahasa Malaysia did not have such linguistic variables in existence. The study also found the use of copula "be" being wrong in most cases with a problem in the subject-verb agreement and relative pronouns. In addition to the structural and syntactic differences in the two languages' sentences, the study also identified other factors such as poor attitudes, disinterest towards learning English, and an unenthusiastic surrounding as hindrances to learning English.

Another study carried out an analysis of essays written by form four students in a semiurban school. Darus and Subramaniam (2009) found out that the students had difficulties in applying correct grammatical rules in the sampled essays. The study was conducted on over fifty students, and the findings were in support of the two previous research reports. The study also highlighted common errors in grammar made by the students. The subject-verb agreement was the most common error, followed by the wrong use of singular and plural forms. The students also had problems with the use of tense, prepositions, and inappropriate choice of words. The study findings imply that the students had not yet grasped the most basic sentence structures and grammar even though they had been in school for numerous years learning English.

Evidence from a study by Stapa and Abdul Majid (2006) indicates that the use of the national language in writing instruction promoted better writing literacy in learners with limited English proficiency. Through an experimental research study, the researchers corroborate that using Bahasa Malaysia to teach students with limited ability in English has a positive impact. The use of the national language in developing ideas led to the production of essays that were of better quality overall. The criteria for determining quality were through overall scores, the content, organisation, and language.

Another study by Rahman (2005) confirms that the use of the national language, Bahasa Malaysia, has a positive impact when used in English class instruction. She asserts that the use of Bahasa Malaysia has a positive effect on her respondents' process of learning English. The research reported that her students felt comfortable explaining problematic 
English language passages in Bahasa Malaysia. The respondents also enjoyed using translation resources at their disposal and facilitating a better understanding of texts. However, not all researchers seem to agree on using Bahasa Malaysia in teaching the English language. According to his findings, Ali (2008) argues that teachers used the national language because of the pressure to have their students get good grades in their exams.

Nambiar, Noraini Ibrahim, and Pamela seem to concur concerning the issue. The researchers conducted a study to examine the language learning strategies among form two students. The study results indicated an underutilisation of language learning strategies, and that the participants' underdevelopment of the said strategies was to blame for the weaknesses. The study revealed that learners preferred using language-learning strategies that required little critical and analytical effort. Over $60 \%$ of the respondents admitted to having to rely on Bahasa Malaysia to comprehend English literacy texts.

Research studies carried out at the secondary school level in Malaysia offer a glimpse of the state of English literacy in the country since the language is generally acquired at that level (Azman, 2009). The majority of the students in Malaysia live in rural areas and rarely experience contact with English. Generally, the studies discussed regarding English learning in secondary schools in Malaysia indicate that Bahasa Malaysia has a very strong influence on the English learning process. The use of the mother tongue interferes with the way English is learned and used. Bahasa Malaysia can be attributed to the wrong use of grammar rules, syntax, and morphology. The majority of the students were found to refer to their mother tongue while writing essays. There was also an observed use of direct translations or use of dictionaries to get meanings of words and comprehend texts in English.

The Malaysian system of education emphasises reading and writing skills that are purely focused on the mastery of grammar rules. These are the tested items in both the school and national examinations. This means that learning English in this context involves its mechanics without connecting it to real-life communication activities (Bykonia et al., 2019). The element of socio-cultural language learning is neglected, and students have fixed ways of using the language.

\section{Research Methodology Methods of Finding Literature}

For this research study, a literature review was conducted to evaluate the available resources regarding English Language Learning Strategies, ESP, and the Business English subject matter. In this report, academic resources such as articles, books, and other relevant information are used to increase knowledge about the topic. The study explores literature that exists concerning English Language Learning and ESP in Malaysia and the context of the world. For this specific study, a literature search and evaluation were conducted to sort out the relevant material.

\section{Inclusion Criterion}

For this study, the included papers provided guidance on the methodology of directing a literature review. The literature that was included covered topics dealing with English Language Learning, ESP, and English Language Learning Strategies. The study paid special attention to education and relevant literature concerning the English language and ESP and the strategies used in learning both. The research review focused on studies that were written in English. 


\section{Identifying Literature}

The literature search for this study involved keywords such as "English Language Learning Strategies," "Literature for English for Specific Purposes," "English Language Learning Strategies Adopted by ESP Students in learning," "English Language Learning for Students in Malaysia," and other related keywords. For each of the identified research papers, a preliminary relevance was determined through its title. Regarding the title, the content was used to ascertain the subject matter. The manuscripts that discussed the subject matter and the relevant literature review were used. For such resources, the full reference was taken, and it included the author(s), the year of publication, and the abstract of the material for further analysis and evaluation.

The search process involved the use of various databases to access the materials. Scholarly domains such as JSTOR, Google Scholar, ERIC, Sage, and Google were used. Out of the five, the Education Resources Information Center (ERIC) was the most commonly used. The reason behind it is that it is an online digital library concerned with educational research and related information. Because of the limited scope of the research regarding the available information, the study did not have any limitations to the date of publication of the materials used. The only concern was the relevance of the materials and not the publication date.

\section{Screening}

After searching for the relevant materials for the study, the obtained search record was of over fifty materials. Out of the acquired materials, fifty relevant documents were screened for inclusion for this research study. The fifty studies that were settled on from the screening and their relevance were recorded for further analysis of the findings and relevant assessment.

\section{Assessment for Eligibility and Quality}

After obtaining the relevant articles, skimming was done on the full-text articles for further evaluation. The main reason was to check for the quality and the eligibility of the studies. Regarding this, books and journal articles were included. However, before inclusion, the reputation of the publishers was scrutinised, and those deemed reliable were used. Apart from books and journal articles, very few high-quality reports were used. These reports had to be assessed to check their quality as well. Quality in this context revolved around the cited references used in the reports. Before including the articles for the study, a series of iterations were conducted. Forward and backward searches were conducted to identify the literature review techniques utilised for the analyses. It was also completed to filter out articles related to Malaysia's context and business English.

Generally, the inclusion criteria involved publications that were academic in nature and peer-reviewed studies. In this case, the material must have explored the learning of English for Specific Purposes. The exclusion criteria involved disregard for no academic materials, poorly conducted research studies, and ill-reputed publishers. The mainly used databases for searching the materials were ERIC and Google Scholar. The two databases were essential because they provided academic resources in nature and with the option of filtering peer-reviewed sources.

\section{Results}

After conducting the mentioned process of systematic review, the result can be seen below. 
Table 1: Summary of the past related studies related to the reading strategies in learning English language

\begin{tabular}{|c|c|c|c|}
\hline Article & $\begin{array}{l}\text { Number of } \\
\text { participants in the } \\
\text { studies }\end{array}$ & Research design & Results \\
\hline $\begin{array}{l}\text { Darus \& } \\
\text { Subrama } \\
\text { niam } \\
(2009)\end{array}$ & $\begin{array}{l}\text { The study evaluates } \\
\text { errors in a corpus of } \\
72 \text { essays written by } \\
72 \text { participants } \\
\text { sampled from Form } \\
\text { Four students from a } \\
\text { secondary school in } \\
\text { Malaysia }\end{array}$ & $\begin{array}{l}\text { Comprehensive } \\
\text { review of written } \\
\text { essays and Markin } \\
\text { software }\end{array}$ & $\begin{array}{l}\text { The results identified verb tense, } \\
\text { preposition, word order, } \\
\text { singular/plural form, word choice, } \\
\text { and subject-verb agreement as the } \\
\text { six most frequent errors among ESL } \\
\text { learners. The results highlighted the } \\
\text { common areas of struggle for ESP } \\
\text { students on which the preparation of } \\
\text { effective teaching materials should } \\
\text { focus }\end{array}$ \\
\hline $\begin{array}{l}\text { Kaur \& } \\
\text { Clarke } \\
\text { (2009) }\end{array}$ & $\begin{array}{l}\text { The study sample } \\
\text { comprised of } 3 \\
\text { managers and } 25 \\
\text { employees from the } \\
\text { HR departments of } \\
\text { two US corporations } \\
\text { in Penang, Malaysia }\end{array}$ & $\begin{array}{l}\text { The researchers } \\
\text { used } \\
\text { questionnaires and } \\
\text { interviews to } \\
\text { collect data }\end{array}$ & $\begin{array}{l}\text { The findings identified } \\
\text { communicative events such as } \\
\text { speaking during or chairing meetings, } \\
\text { editing written materials, and writing } \\
\text { reports as important in the } \\
\text { development of language skills. }\end{array}$ \\
\hline $\begin{array}{l}\text { Kavaliaus } \\
\text { kienè } \\
(2009)\end{array}$ & $\begin{array}{l}\text { The participants } \\
\text { included } 55 \\
\text { students, aged } 18 \text { to } \\
22 \text {, studying English } \\
\text { for Specific Purposes } \\
\text { (ESP). The students } \\
\text { were predominantly } \\
\text { females at the } \\
\text { intermediate and pre } \\
\text {-intermediate levels, } \\
\text { majoring in Social } \\
\text { Sciences at the } \\
\text { Mykolas Romeris } \\
\text { University, Vilnius, } \\
\text { Lithuania }\end{array}$ & $\begin{array}{l}\text { The study used the } \\
\text { survey method to } \\
\text { collect data which } \\
\text { was later analysed } \\
\text { using the Statistical } \\
\text { Package for the } \\
\text { Social Sciences } \\
\text { (SPSS) software }\end{array}$ & $\begin{array}{l}\text { Based on the findings, all learners } \\
\text { require the support of } L 1 \text { in English } \\
\text { classes. However, the level of } \\
\text { support depends on the learner's } \\
\text { proficiency in English language. }\end{array}$ \\
\hline $\begin{array}{l}\text { Razawi } \\
\text { et al } \\
(2011)\end{array}$ & $\begin{array}{l}\text { Participants included } \\
99 \text { students of Kuala } \\
\text { Berang, Terengganu, } \\
\text { and SMK Seri Berang. }\end{array}$ & $\begin{array}{l}\text { The study used } \\
\text { questionnaires and } \\
\text { analysed the } \\
\text { results using SPSS }\end{array}$ & $\begin{array}{l}\text { The results categorised students' } \\
\text { learning styles into impulsive, } \\
\text { extroverted, ambiguity tolerant, } \\
\text { visual, global, perceiving, active, } \\
\text { introverted, auditory, and } \\
\text { sociological learners. Therefore, } \\
\text { instructors need to use lesson plan } \\
\text { effectively to take care of the need of } \\
\text { these diverse learning styles }\end{array}$ \\
\hline
\end{tabular}




\begin{tabular}{|c|c|c|c|}
\hline $\begin{array}{l}\text { Patil \& } \\
\text { Karekatti } \\
(2012)\end{array}$ & $\begin{array}{l}\text { The study sampled } \\
100 \text { engineering } \\
\text { students at an } \\
\text { engineering college } \\
\text { in Western } \\
\text { Maharashtra }\end{array}$ & $\begin{array}{l}\text { Researchers used } \\
\text { questionnaires to } \\
\text { collect data }\end{array}$ & $\begin{array}{l}\text { The study returned that } 48 \%, 43 \% \text {, } \\
\text { and } 9 \% \text { of engineering students } \\
\text { perceive themselves to possess high, } \\
\text { medium, and low communication } \\
\text { apprehension while communicating } \\
\text { in English language respectively. The } \\
\text { level of apprehension is high in oral } \\
\text { presentation and public speaking } \\
\text { compared to group discussions }\end{array}$ \\
\hline $\begin{array}{l}\text { Prachana } \\
\text { nt (2012) }\end{array}$ & 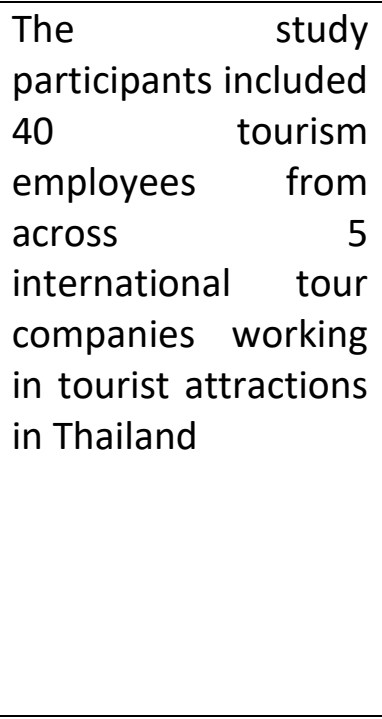 & $\begin{array}{l}\text { Researchers used } \\
\text { questionnaires } \\
\text { presented in three } \\
\text { parts: a 5-rating } \\
\text { scale, a checklist, } \\
\text { and an open-ended } \\
\text { form. They used } \\
\text { SPSS to analyse } \\
\text { data }\end{array}$ & $\begin{array}{l}\text { Based on the findings, speaking is the } \\
\text { most essential step, followed by } \\
\text { listening, reading, and writing } \\
\text { respectively in learning English } \\
\text { language. The three most important } \\
\text { functions of English language in this } \\
\text { sector are offering help, providing } \\
\text { services, and giving information. } \\
\text { Challenges in the use of English } \\
\text { language include insufficient } \\
\text { vocabulary, lack of grammar } \\
\text { knowledge, inappropriate words and } \\
\text { expressions, an inability to } \\
\text { understand foreign accents }\end{array}$ \\
\hline $\begin{array}{l}\text { Ahmad } \\
\text { (2013) }\end{array}$ & $\begin{array}{l}500 \text { students from } 15 \\
\text { learning institutions }\end{array}$ & $\begin{array}{l}\text { This paper used the } \\
\text { survey method and } \\
\text { analysis of reports } \\
\text { to assess the } \\
\text { structure of } \\
\text { entrepreneurship } \\
\text { education at the } \\
\text { different } \\
\text { educational levels }\end{array}$ & $\begin{array}{l}\text { The study returned that } \\
\text { governments should not equate } \\
\text { enterprise education exclusively to } \\
\text { any specific learning institutions; } \\
\text { rather, this education needs to be } \\
\text { distributed throughout all phases of } \\
\text { the education systems. }\end{array}$ \\
\hline $\begin{array}{l}\text { Kim } \\
(2013)\end{array}$ & $\begin{array}{lr}\text { The participants } \\
\text { included } & 99 \\
\text { students, } & 30 \\
\text { engineering } & \\
\text { professors, and } & 43 \\
\text { industry workers } & \end{array}$ & $\begin{array}{l}\text { The study used } \\
\text { questionnaire } \\
\text { survey and } \\
\text { unstructured } \\
\text { interviews }\end{array}$ & $\begin{array}{l}\text { Based on the results, } 63 \% \text { of } \\
\text { engineering professors are not } \\
\text { satisfied with the students' English } \\
\text { abilities. About } 67 \% \text { of the industry } \\
\text { workers interviewed are not satisfied } \\
\text { with English abilities of staff. The } \\
\text { unsatisfactory skills are reading } 53 \% \text {, } \\
\text { listening } 43 \% \text {, speaking } 53 \% \text {, and } \\
\text { writing } 50 \% \text {. }\end{array}$ \\
\hline $\begin{array}{l}\text { Ashrafza } \\
\text { deh \& } \\
\text { Nimehch } \\
\text { isalem } \\
(2015)\end{array}$ & $\begin{array}{l}\text { The study collected } \\
69 \text { samples from an } \\
\text { intact group of } \\
\text { learners }\end{array}$ & $\begin{array}{l}\text { The study assigned } \\
\text { two raters to } \\
\text { undertake an } \\
\text { analytic writing } \\
\text { scale to score the }\end{array}$ & $\begin{array}{l}\text { Results revealed that } 70 \% \text { of } \\
\text { participants attained 'excellent to } \\
\text { very good' scores for the 'content' of } \\
\text { their written samples. About } 75 \% \\
\text { scored 'fair to poor' on 'organisation' } \\
\text { and } 97 \% \text { scored 'fair to poor' on }\end{array}$ \\
\hline
\end{tabular}




\begin{tabular}{|c|c|c|c|}
\hline & & $\begin{array}{l}\text { samples } \\
\text { individually }\end{array}$ & $\begin{array}{l}\text { 'vocabulary'. Majority of the } \\
\text { participants reported 'good to } \\
\text { average' results on 'language use' } \\
\text { and 'mechanics' skills. These findings } \\
\text { demonstrated the need for urgent } \\
\text { remedy course to aid the students } \\
\text { improve their vocabulary and } \\
\text { organisational skills in ESP writing. } \\
\text { Other areas of concern are narrative } \\
\text { and argumentative skills. }\end{array}$ \\
\hline $\begin{array}{l}\text { Benragh } \\
\text { da et al } \\
\text { (2017) }\end{array}$ & $\begin{array}{l}\text { The study used } \\
\text { random sampling to } \\
\text { select } 234 \text { students } \\
\text { from overall } 636 \\
\text { undergraduate } \\
\text { students }\end{array}$ & $\begin{array}{l}\text { The study used } \\
\text { questionnaire and } \\
\text { semi-structured } \\
\text { interviews, then } \\
\text { analysed the } \\
\text { results using SPSS }\end{array}$ & $\begin{array}{l}\text { The results indicated that the } \\
\text { undergraduate possess an optimistic } \\
\text { attitude towards oral English } \\
\text { presentations and their scores. It } \\
\text { identified impediments to successful } \\
\text { oral presentation which include } \\
\text { classroom atmosphere, poor English } \\
\text { language proficiency, and anxiety. }\end{array}$ \\
\hline $\begin{array}{l}\text { Bykonia } \\
\text { et al } \\
(2019)\end{array}$ & $\begin{array}{lr}\text { The researchers } \\
\text { surveyed } 1241 \text { first } \\
\text { year students and } \\
\text { tutors from } 11 \\
\text { universities from } \\
\text { across Ukraine }\end{array}$ & $\begin{array}{l}\text { The study } \\
\text { employed a multi- } \\
\text { method method to } \\
\text { collect data and } \\
\text { quantitative } \\
\text { method to analyse } \\
\text { the data. } \\
\text { Superficially, the } \\
\text { researchers used } \\
\text { Covariance-based } \\
\text { Structural Equation } \\
\text { Modeling (SEM) } \\
\text { software such as } \\
\text { Textalyzer, AMOS, } \\
\text { and SPSS to analyse } \\
\text { the feedbacks to } \\
\text { the survey } \\
\text { questions }\end{array}$ & $\begin{array}{l}\text { The results reported a better desire } \\
\text { among students to engage } \\
\text { independently with efficient problem } \\
\text { solving, improved time management, } \\
\text { computer-assisted work, lifelong } \\
\text { learning skills, and increased } \\
\text { motivation to study. It further } \\
\text { observed a shift from a teacher- } \\
\text { centred to student-centred learning } \\
\text { approach, which integrates } \\
\text { multimedia tools into teaching, } \\
\text { specifically the use of multimedia } \\
\text { textbooks }\end{array}$ \\
\hline $\begin{array}{l}\text { Damanik } \\
(2020)\end{array}$ & $\begin{array}{l}\text { The study surveyed } \\
1200 \text { participants }\end{array}$ & $\begin{array}{l}\text { The study } \\
\text { developed } \\
\text { questionnaires to } \\
\text { measure speaking, } \\
\text { reading, writing, } \\
\text { and listening skills. } \\
\text { Moreover, it used } \\
\text { the adoption of } \\
\text { product } \\
\text { development steps } \\
\text { by Sugiyono. }\end{array}$ & $\begin{array}{l}\text { The study found Cooperative } \\
\text { Learning as the most effective } \\
\text { method for the development of } \\
\text { foreign language skills. It emphasises } \\
\text { the direct practice of the aptitude to } \\
\text { apply foreign language listening, } \\
\text { writing, speaking, and reading }\end{array}$ \\
\hline
\end{tabular}




\begin{tabular}{|c|c|c|c|}
\hline $\begin{array}{l}\text { Azmuddi } \\
\mathrm{n} \text { et al } \\
(2020)\end{array}$ & $\begin{array}{l}\text { The study used focus } \\
\text { group interviews and } \\
\text { online annotations } \\
\text { to collect data from } \\
12 \text { students taking a } \\
\text { course on English for } \\
\text { Technical } \\
\text { Communication at a } \\
\text { public university on } \\
\text { the East Coast of } \\
\text { Peninsular Malaysia. }\end{array}$ & $\begin{array}{l}\text { The researchers } \\
\text { undertook } \\
\text { thematic, } \\
\text { descriptive analysis } \\
\text { of data using NVivo } \\
\text { and SPSS software. }\end{array}$ & $\begin{array}{l}\text { Based on the results, students in an } \\
\text { online reading environment attained } \\
\text { better reading comprehension } \\
\text { facilitated by digital annotation tools }\end{array}$ \\
\hline $\begin{array}{l}\text { Jamalai } \\
\& \\
\text { Krish } \\
(2021)\end{array}$ & $\begin{array}{l}\text { The study collected } \\
\text { data from a group of } \\
26 \text { undergraduate } \\
\text { students studying for } \\
\text { different majors }\end{array}$ & $\begin{array}{l}\text { The research was in } \\
\text { the form a case } \\
\text { study founded on } \\
\text { the Partnership for } \\
\text { 21st Century } \\
\text { Learning } \\
\text { framework and } \\
\text { Socio- } \\
\text { Constructivism } \\
\text { theory and }\end{array}$ & $\begin{array}{l}\text { According to the findings, students } \\
\text { perceived the online discussion } \\
\text { forum (ODF) as beneficial in fostering } \\
21^{\text {st }} \text { century learning skills and } \\
\text { facilitative English language learning. } \\
\text { The use of ODF had a positive } \\
\text { outcome on the development of } \\
\text { attentiveness, confidence, flexibility, } \\
\text { and reference for documentation. } \\
\text { Moreover, the participants perceived } \\
\text { the online learning environment as } \\
\text { integral in the development of } \\
\text { leadership, time management, } \\
\text { critical thinking, discipline, and digital } \\
\text { skills }\end{array}$ \\
\hline
\end{tabular}

Table 2: Summary of the past related studies related to the LLS in learning English language

\begin{tabular}{|c|c|c|c|}
\hline Article & $\begin{array}{c}\text { Number of } \\
\text { participants in the } \\
\text { studies }\end{array}$ & Research design & Results \\
\hline $\begin{array}{l}\text { Pašalić } \\
\text { (2013) }\end{array}$ & $\begin{array}{l}\text { The sample included } \\
201 \text { students at the } \\
\text { University of Split, } \\
\text { Faculty of } \\
\text { Economics. The } \\
\text { sample had } 70 \% \text { 1st } \\
\text { year students and } \\
\begin{array}{l}30 \% \text { 2nd year } \\
\text { students }\end{array}\end{array}$ & $\begin{array}{l}\text { The study utilised } \\
\text { the Strategy } \\
\text { Inventory for } \\
\text { Language Learning } \\
\text { (SILL) (Oxford, } \\
\text { 1990) } \\
\text { questionnaire to } \\
\text { examine students' } \\
\text { strategies }\end{array}$ & $\begin{array}{l}\text { The findings showed that } \\
\text { participants apply cognitive, } \\
\text { metacognitive, social, memory, } \\
\text { affective, and compensation } \\
\text { strategies for language learning. Of } \\
\text { all these six strategies, compensation } \\
\text { strategies are the most used by the } \\
\text { students. Based on the findings, } \\
\text { compensation strategies enable } \\
\text { students to understand English } \\
\text { words by describing what they want } \\
\text { to say or using synonyms. }\end{array}$ \\
\hline
\end{tabular}




\begin{tabular}{|c|c|c|c|}
\hline $\begin{array}{l}\text { Shah et } \\
\text { al (2013) }\end{array}$ & $\begin{array}{l}\text { Participants included } \\
312 \text { Malay-speaking } \\
\text { undergraduate } \\
\text { students from a } \\
\text { public English- } \\
\text { medium university in } \\
\text { Malaysia }\end{array}$ & $\begin{array}{l}\text { The study } \\
\text { methodology was } \\
\text { LLS of Oxford's } \\
(1990) \text { Strategy } \\
\text { Inventory for } \\
\text { Language Learning } \\
\text { (SILL). }\end{array}$ & $\begin{array}{l}\text { The study found that } 69.1 \% \text { of } \\
\text { participants spoke mainly Malay at } \\
\text { home while } 30.9 \% \text { spoke both Malay } \\
\text { and English at home. About } 97.4 \% \\
\text { enjoy learning English with } 85.6 \% \\
\text { and } 14.4 \% \text { considering English } \\
\text { language as very important and } \\
\text { important respectively. The findings } \\
\text { of the study showed the following } \\
\text { learning strategy ranking of LLS: } \\
\text { Social, Compensation, Cognitive, } \\
\text { Affective, } \\
\text { Memory. }\end{array}$ \\
\hline $\begin{array}{l}\text { Rustam, } \\
\text { Hamra \& } \\
\text { Weda } \\
(2015)\end{array}$ & $\begin{array}{l}30 \text { students of } \\
\text { nautical study } \\
\text { program in the } \\
\text { fourth semester }\end{array}$ & $\begin{array}{l}\text { The study } \\
\text { employed } \\
\text { descriptive } \\
\text { quantitative } \\
\text { method. } \\
\text { questionnaire } \\
\text { version } 7.0 \text { was } \\
\text { used as research } \\
\text { instrument as well } \\
\text { as their English skill } \\
\text { test results. }\end{array}$ & $\begin{array}{l}\text { Metacognitive Strategy was found to } \\
\text { be dominantly used strategies in } \\
\text { learning English skill which applied } \\
36.67 \% \text { ( } 11 \text { students), followed by } \\
\text { Compensation Strategy with } 23.33 \% \\
\text { ( } 7 \text { students), Social Strategy with } \\
13.33 \% \text { ( } 4 \text { students). These three } \\
\text { strategies followed by Memory and } \\
\text { Cognitive Strategy with } 10 \% \text { ( } 3 \\
\text { students) for each strategy, and } \\
\text { Affective Strategy with } 6.67 \% \text { ( } 2 \\
\text { students). Reading and writing skills } \\
\text { were more prevalent among } \\
\text { successful students who employed } \\
\text { metacognitive and compensatory } \\
\text { strategies than other skills. On the } \\
\text { contrary, the unsuccessful students } \\
\text { who used memory, cognitive, and } \\
\text { affective learning strategies } \\
\text { outperformed their peers in writing } \\
\text { and listening. }\end{array}$ \\
\hline $\begin{array}{l}\text { Hungyo } \\
\text { (2015) }\end{array}$ & $\begin{array}{l}26 \text { Thai } \\
\text { students }\end{array}$ & $\begin{array}{l}\text { Quantitative } \\
\text { approach by using } \\
\text { the Strategy } \\
\text { Inventory for } \\
\text { Language Learning } \\
\text { (SILL). }\end{array}$ & $\begin{array}{l}\text { Most students who were in the ' } A \text { ' } \\
\text { range academic grade used a range } \\
\text { of various strategies from memory, } \\
\text { cognitive, compensation, } \\
\text { metacognitive, affective and social } \\
\text { strategies. Meanwhile, students who } \\
\text { scored D and } F \text { will resort to } \\
\text { metacognitive, affective and social } \\
\text { strategies only. }\end{array}$ \\
\hline
\end{tabular}




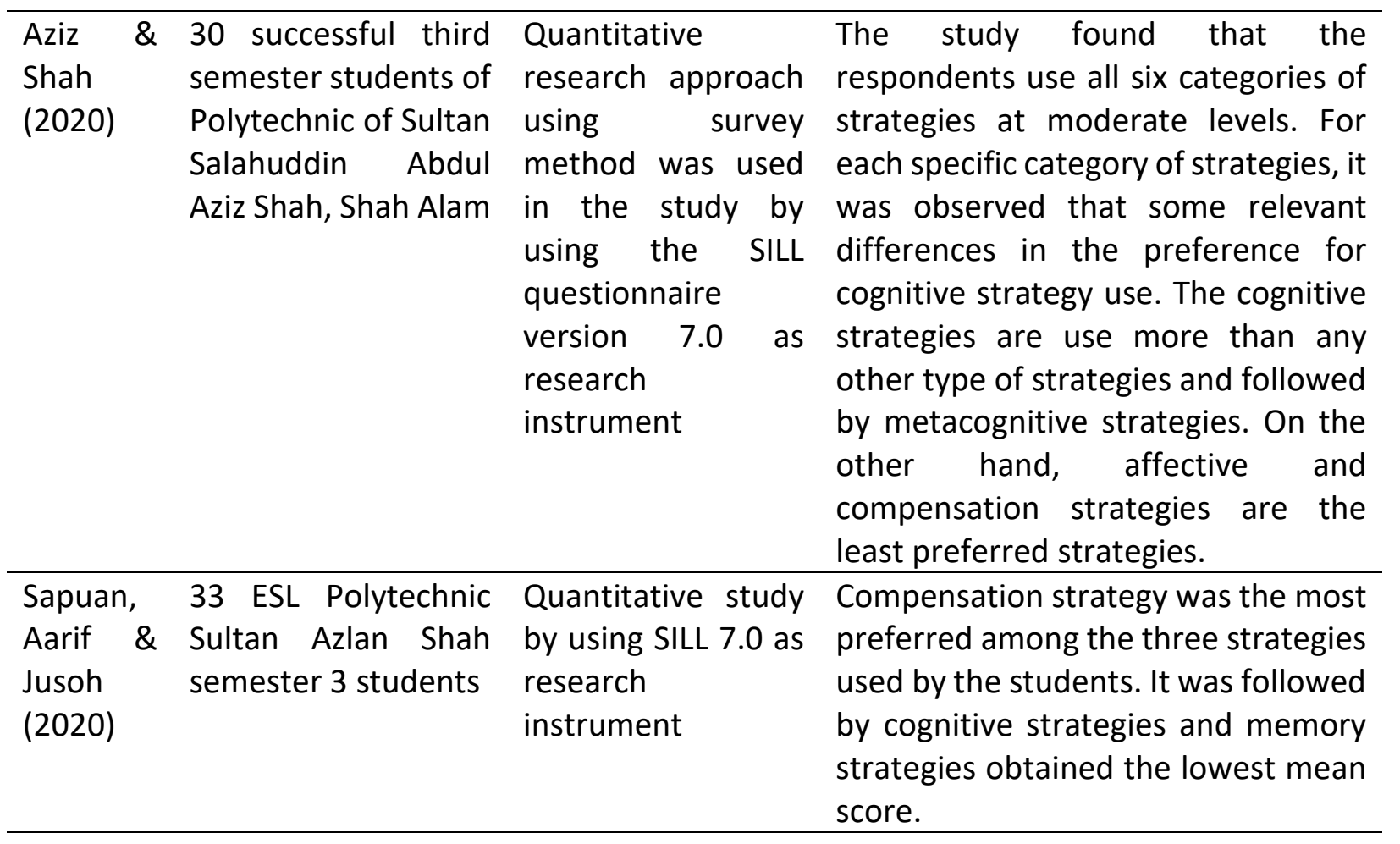

\section{Conclusion}

The systematic review of the research journals, reports, and books on definitions and growth and development of ESP, importance of speaking and writing, and strategies for learning ESP has revealed a gap in the English proficiency in the Malaysian education system. The findings indicate that most ESP students in Malaysia have adopted self-directed English Language Learning strategies that have boosted the outcome of their language learning efforts. While these strategies, especially compensation strategies, have been useful in learning English language, there is the need for an inclusive pedagogical approach to make them more effective in developing ESP language proficiency. The study found a lack of clarity as regards the Malaysian government's plans, policies, and ways forward on the development of English proficiency skills in learners across the education system. An exploration of the studies outside Malaysia shows that other countries have taken steps in embracing business English. The emphasis has been on the assessments of the needs of students with regard to English learning (Bhatia \& Bremner, 2012). Therefore, to enhance the competitiveness of the Malaysian ESP students, the government needs to undertake an education reform that focuses on the application of cognitive, metacognitive, social, memory, affective, and compensation strategies for English language learning.

\section{Limitations and Recommendations Limitations}

The inclusion and excursion criteria used in this study limited the number of literature for a review to fifty. This limited sample scope means that the literature review is not adequate to make a conclusive decision on the subject under study. Hence, there is the need for a more in-depth study, which increases the number of literature under review, to reach a conclusive determination. This literature review would form the basis for further studies on this topic. The second limitation was the unavailability of information regarding the impacts of Business English and its adoption in Malaysia. The available literature does not provide 
adequate official records on the impact of Business English and its adoption in Malaysia. Business English is generally a new concept in Malaysia. The third limitation is possible publication bias. The inclusion and excursion criteria could have led to exclusion of studies without statistical significance, but which have reliable information for qualitative analysis of the topic. This is because the procedure focused on magnitude and direction, which would mostly yield literature materials based on empirical studies.

\section{Recommendations}

Drawing from the findings of this systematic review, the government of Malaysia ought to commission research into different strategies that ESP students apply to develop and formulate a new pedagogical policy that would help provide necessary learning support for these students. The present study ought to form the foundation of an in-depth analysis of the different learning strategies to create student-centred learning approaches for successful learning of Business English in Malaysia. Moreover, there is the need to approach the subject of language learning from an out-of-classroom perspective and understand the significance of Business English to students.

\section{References}

Ahmad, S. Z. (2013). The need for inclusion of entrepreneurship education in Malaysia lower and higher learning institutions. Education+ Training.

Ali, M. S. (2008). A case for a case: A qualitative research experience. University of Malaya Press.

Ashrafzadeh, A., \&Nimehchisalem, V. (2015). Vocabulary Knowledge: Malaysian Tertiary Level Learners' Major Problem in Summary Writing. Journal of Language Teaching \& Research, 6(2). $\quad$ https://www.researchgate.net/profile/AnisAshrafzadeh/publication/276841592_Vocabulary_Knowledge_Malaysian_Tertiary_Lev el_Learners'_Major_Problem_in_Summary_Writing/links/5f78434ca6fdcc0086526ecc /Vocabulary-Knowledge-Malaysian-Tertiary-Level-Learners-Major-Problem-inSummary-Writing.pdf

Aziz, A. N. H. (2007). ESL students' perspectives on language anxiety. Unpublished PhD. Thesis, Universiti Putra Malaysia: Serdang.

Aziz, M. S. N. S., \& Shah, M. P. (2020). Language learning strategy (Ils) for english language learners in polytechnic. Journal of Personalized Learning, 3(1) 2020, 71-78.

Azman, H. (2009). English in 1Malaysia: A paradox in rural pluri-literacy practices. Akademika, 76(1). https://ejournal.ukm.my/akademika/article/view/2866

Azmuddin, R. A. A., Nor, N. F. M., \& Hamat, A. (2020). Facilitating Online Reading Comprehension in Enhanced Learning Environment Using Digital Annotation Tools. IAFOR Journal of Education, 8(2), 7-27.

Benraghda, A., Radzuan, N. R. M., \& Ali, Z. (2017). Impediments to delivering oral presentations in English among Malaysian ESP undergraduates. English for Specific Purposes World, 53, 1-13. https://www.researchgate.net/profile/AbdelmadjidBenraghda/publication/318051469_Impediments_to_Delivering_Oral_Presentations_i n_English_among_Malaysian_ESP_Undergraduates/links/595720cba6fdcc2beca39763 /Impediments-to-Delivering-Oral-Presentations-in-English-among-Malaysian-ESPUndergraduates.pdf

Bhatia, V. K., \& Bremner, S. (2012). English for business communication. Language Teaching, 45(4), 410-445. 
Bykonia, O. P., Borysenko, I. V., Zvarych, I. M., Harbuza, T. V., \&Chepurna, M. V. (2019). Teaching Business English to Future Economists Using a Multimedia Textbook. International Journal of Higher Education, 8(4), 115-123. https://eric.ed.gov/?id=EJ1222696

Chaka, C., \& Booi-Ncetani, N. N. (2015). An investigation into the English reading comprehension of Grade 10 English first additional language learners at a senior secondary school. Reading \& Writing, 6(1), 1-7.

Chalikandy, M. A. (2013). A Comprehensive Method for Teaching English for Specific Purpose. Arab World English Journal, 4(4).

Channa, M. A. (2013). A Study of Needs, Problems, and Wants of Using English of Engineering Students of Quaid-i-Azam University of Engineering, Science and Technology, Pakistan (Doctoral dissertation, Mahidol University).PDF

Damanik, L. A. (2020). Needs analysis of English for specific purpose for sharia business management students. Journal Education and Development, 8(4), 585-585. http://journal.ipts.ac.id/index.php/ED/article/view/2230

Darus, S., \& Subramaniam, K. (2009). Error Analysis of the Written English Essays of Secondary School Students in Malaysia: A Case Study. European Journal of Social Sciences 8(3), 483495.

Darus, S., \& Subramaniam, K. (2009). Error analysis of the written English essays of secondary school students in Malaysia: A case study. European journal of social sciences, 8(3), 483495.

https://www.researchgate.net/profile/SaadiyahDarus/publication/235772401_Error_analysis_of_the_written_english_essays_of_sec ondary_school_students_in_Malaysia_A_case_study/links/0c9605153fc39a74180000 00/Error-analysis-of-the-written-english-essays-of-secondary-school-students-inMalaysia-A-case-study.pdf

Dudley-Evans, T., \& St John, M. (1998). Developments in ESP: A Multi-Disciplinary Approach. Cambridge: Cambridge University Press.

Ellis, M., \& Johnson, C. (1994). Teaching business English. Oxford, England: Oxford University Press.

Hungyo, E. (2015). A study of the language learning strategies used by business students at Asia-Pacific International University, Thailand. Journal of Catalysis, 12(2), 85-93.

Ismail, R. (2008). Factors affecting less proficient ESL learners' use of strategies for language and content area learning (Doctoral dissertation, Universiti Putra Malaysia). https://core.ac.uk/download/pdf/42992947.pdf

Jamalai, M., \& Krish, P. (2021). Fostering 21st century skills using an online discussion forum in an English for specific purpose course. Malaysian Journal of Learning and Instruction, 18(1), 219-240. https://doi.org/10.32890/mjli2021.18.1.9

Kaur, S., \& Clarke, C. M. (2009). Analyzing the English language needs of human resource staff in multinational companies. English for specific purposes, 8(3).

https://www.semanticscholar.org/paper/analysing-the-english-language-needs-of-humanstaff-kaur-clarke/a15ae45e8783f1ff46035be8d9e33af2ad76191a

Kavaliauskienè, G. (2009). Role of mother tongue in learning English for specific purposes. ESP world, 8(1), 1-12. http://esp-world.info/articles_22/PDF/issue_22.pdf

Kim, H. H. (2013). Needs analysis for English for specific purpose course development for engineering students in Korea. International Journal of Multimedia and Ubiquitous Engineering, 8(6), 279-288.

https://citeseerx.ist.psu.edu/viewdoc/download?doi=10.1.1.641.8380\&rep=rep1\&type=pdf 
Krishnakumari, K., Paul-Evanson, C., \& Selvanayagam, S. (2010). Preparing for change: From MUET to academic writing. Paper presented at MyCASELT 2010 The 3rd Malaysia International Conference on Academic Strategies in English Language Teaching, at The Saujana Hotel, Kuala Lumpur, 15-16 December 2010.

Lackstrom, J., Selinker, L. \& Trimble, L. 1973. Technical rhetorical principles and grammatical choice. TESOL Quarterly 7 (2), 127-136.

Maros, M., Hua, T. K., \& Salehuddin, K. (2007). Interference in Learning English: Grammatical Errors in English Essay Writing Among Rural Malay Secondary School Students in Malaysia. Jurnal E-Bangi, 2(2), 1-15.

Mazli, M. M. (2007). The effectiveness of an academic reading course in facilitating tertiary students' comprehension of academic texts. Unpublished doctoral dissertation, Universiti Kebangsaan Malaysia, Malaysia.

Mustaffa, R. (2009). The effects of culture on students' learning styles. Journal of Language Teaching, Linguistics and Literature, 12, 83-94.

Nambiar, R. M. (2007). Enhancing academic literacy among tertiary learners: A Malaysian experience. 3L: Language, Linguistics, Literature ${ }^{\circledR}, 13$.

Paltridge, B., \& Starfield, S. (Eds.). (2014). The handbook of English for specific purposes. John Wiley \& Sons.

Pandian, A. (2002). English language teaching in Malaysia today. Asia Pacific Journal of Education, 22(2), 35-52. https://doi.org/10.1080/0218879020220205

Pašalić, M. (2013). Language learning strategies and progress in EFL of students of economics and business. ESP Today, 1(1), 127-138

Patil, M. S., \& Karekatti, T. (2012). Correlation between level of communication apprehension and development of communication skills in engineering students. English for Specific Purposes World, 36(12), 1-15

Prachanant, N. (2012). Needs analysis on English language use in tourism industry. ProcediaSocial and Behavioral Sciences, 66, 117-125. https://doi.org/10.1016/j.sbspro.2012.11.253

Rahman, R. A. (2005). Learning English from learners' perspective.

Razawi, N. A., Muslim, M., Razali, S. M. C., Husin, N., \& Samad, N. Z. A. (2011). Students' diverse learning styles in learning English as a second language. International Journal of Business and Social Science, 2(19).

http://www.ijbssnet.com/journals/Vol_2_No_19_Special_Issue_October_2011/22.pdf

Rustam, N. S., Arifuddin Hamra, A., \& Weda, S. (2015). The Language Learning Strategies Used by Students of Merchant Marine Studies Polytechnics Makassar. ELT Worldwide Journal of English Language Teaching 2(2), 77-94.

Sapuan, A. F., Aarif, F., \& Jusoh, N. (2020). Utilisation of language learning strategies in esl context for semester 3 students of Polytechnic Sultan Azlan Shah. Retrieved from https://www.researchgate.net/profile/Ahmad-

Sapuan/publication/344234659_UTILISATION_OF_LANGUAGE_LEARNING_STRATEGIE S_IN_ESL_CONTEXT_FOR_SEMESTER_3_STUDENTS_OF_POLYTECHNIC_SULTAN_AZLA N_SHAH/links/5f5ee54f299bf1d43c01c991/UTILISATION-OF-LANGUAGE-LEARNINGSTRATEGIES-IN-ESL-CONTEXT-FOR-SEMESTER-3-STUDENTS-OF-POLYTECHNIC-SULTANAZLAN-SHAH.pdf

Shah, M. I. A., Ismail, Y., Esa, Z., \& Muhamad, A. J. (2013). Language Learning Strategies of English for Specific Purposes Students at a Public University in Malaysia. English Language Teaching, 6(1), 153-161. https://eric.ed.gov/?id=EJ1076808 
Stapa, S., \& Abdul Majid, A. (2006). The use of first language in limited english proficiency classes: good, bad or ugly?. e-BANGI: Jurnal Sains Sosial dan Kemanusiaan, [online] 1(1). http://journalarticle.ukm.my/1516/.

Uribe-Enciso, O. L. (2015). Improving EFL students' performance in reading comprehension through explicit instruction in strategies. Rastros Rostros, 17, 37-52. 